\title{
Incentives for technological innovation: a study of the public policy of tax exemption in Brazil
}

\author{
Geciane Silveira Porto ${ }^{1}$ \\ Caroline Viriato Memória² \\ 1 Universidade de São Paulo / Faculdade de Economia, Administração e Contabilidade, Ribeirão Preto / SP — Brazil \\ ${ }^{2}$ Universidade de Fortaleza / Programa de Pós-graduação em Direito, Fortaleza / CE — Brazil
}

\begin{abstract}
The goal of this paper is to explain relations between investments in Research and Development - R\&D and innovation's outcomes between the 2009s and 2013s in companies that are encouraged by the Lei do Bem (Good Law), which regulates tax incentives for technological innovation. Econometric Logit models were estimated for fixed effects. The analysis results indicate that the probability of firms presenting innovations in general (in products, processes or services) or only in products depends on the size of the company and the amount invested in $\mathrm{R} \& \mathrm{D}$, particularly it depends on the investment in human resources - HR. On the other hand, the chances of firms innovate in process are limited to the size of the company, the spending specifically to develop HR programs. The results confirm that investments in R\&D from the beneficiaries produce innovation's outcomes.
\end{abstract}

Keywords: investment in Research and Development; Lei do Bem; innovation outcome.

\section{Incentivos para inovação tecnológica: um estudo da política pública de renúncia fiscal no Brasil}

Este artigo tem por objetivo explicar relações entre os investimentos em pesquisa e desenvolvimento (P\&D) e os resultados da inovação entre os anos de 2009 e 2013 em empresas beneficiárias dos incentivos para inovação tecnológica da Lei n. 11.196 (2005) - a chamada Lei do Bem. São estimados modelos econométricos logit para efeitos fixos e modelos de probabilidade linear com efeitos fixos. Os resultados indicam que a probabilidade das beneficiárias inovarem em produtos, processos ou serviços, ou apenas em produtos, depende do tamanho da empresa e do montante investido em $\mathrm{P} \& \mathrm{D}$, principalmente em recursos humanos $(\mathrm{RH})$. As chances das empresas inovarem em processos se relacionam ao tamanho da empresa, aos gastos e aos programas de desenvolvimento de RH. Logo, os resultados confirmam que os investimentos em P\&D das beneficiárias geram resultados de inovação tecnológica.

Palavras-chave: investimento em pesquisa e desenvolvimento; Lei do Bem; resultado da inovação.

\section{Incentivos para la innovación tecnológica: el estudio de la política pública de renuncia en Brasil}

El objetivo de este artículo es explicar relaciones entre las inversiones en investigación y desarrollo (I+D) y los resultados de la innovación entre los años 2009 y 2013 en empresas beneficiarias de los incentivos para innovación tecnológica de la Ley 11.196/2005 (Lei do Bem-Lei del Bien). Se estiman los modelos econométricos Logit para efectos fijos y modelos de probabilidad lineal con efectos fijos. Los resultados indican que la probabilidad de que las empresas innoven en productos, procesos o servicios, o solo en productos, depende del tamaño de la empresa y del monto invertido en I+D, principalmente en recursos humanos (RR. HH.). Las posibilidades de que las empresas innoven en el proceso se limitan al tamaño de la empresa, a los gastos y a los programas de desarrollo de RR. HH. Por lo tanto, los resultados confirman que las inversiones en Investigación y Desarrollo de las beneficiarias producen resultados de innovación tecnológica.

Palabras clave: inversiones en investigación y desarrollo; Lei do Bem; Ley del Bien; resultados de la innovación. 


\section{INTRODUCTION}

In addition to private research and development activities (R\&D), the state acts to correct market imperfections and impacts on investment in R\&D activities and on economic growth. As the realization of R\&D activities is translated by the existence of technological risks, the State can share these risks with entrepreneurs, provided that they can demonstrate their ability to invest in R\&D.

$R \& D$ projects seek to present results for a given problem or a difficulty that represents a clear improvement for the company. The activities performed to overcome the problem may result in a solution or not to the identified problem. However, $R \& D$ activities always present a result, even if it is a guideline that a certain premise adopted and tested for overcoming a technological barrier should not be followed.

The Brazil has an important set of instruments to support innovation. Among the legal means is the Good Law ${ }^{1}$, which regulates the public policy that has as target audience companies that develop technological innovation based on $R \& D$ and that operate in a regime of taxation of the real profit. The objective of this policy is to stimulate private investments in technological $\mathrm{R} \& \mathrm{D}$, both in the design of new products and in the manufacturing process, aiming at greater competitiveness in the market. The Good Law considers investment in R\&D of companies: expenses classified as operating under the legislation of Corporate Income Tax (IRPJ) aimed at development of technological innovation projects and $R \& D$; training, salaries and social and labor charges of researchers; prototypes and consumables; contracts with universities and research institutes.

The Good Law regulates a public policy predominantly focused on the industrial sector, but also includes companies from the service sector and state-owned companies. The greater part of the fiscal stimulus to technological innovation, established by the Good Law, refers to the tax exemption, by means of a reduction in the calculation base when calculating the IRPJ and the Social Contribution on Net Income (CSLL), although companies may also opt for the tax exemption applied to the calculation of the Industrialized Products Tax (IPI) when purchasing equipment for R\&D.

With the investment policy to technological innovation through tax exemption, the Federal Government gives up tax revenue that could be allocated to essential public services, such as public security, education, health, transportation. Hence the importance of this article, which contributes to the analysis of the results of the cross-checking of secondary data related to the tax renunciation program of Chapter III of the Good Law.

Thus, this study is justified in terms of its empirical and analytical character, which seeks to explore the relationships between innovative capabilities, tax exemption and innovation, at the same time as it seeks to validate theoretical propositions. This research is inserted in a theoretical gap little considered and that represents a tendency of the studies of the area of innovation, innovation systems and capabilities to innovate.

The research was carried out based on secondary data provided by the Ministry of Science, Technology, Innovation and Communications (MCTIC), through the form for information on the

\footnotetext{
1 "The law n. 11.196 (2005) is known as the Good Law, but in this study the section is limited to the theme of its Chapter III, arts. 17 to 26 , which deals exclusively with the incentives for technological innovation in the form of tax exemption. Thus, all references to the term "Good Law" refer to Chapter III of Law n. 11.196 (2005).
} 
activities of Technological Research and Development of Technological Innovation in companies (FORMR\&D), in which companies participating in the Tax Incentives program to Technological Research Activities and Technological Innovation Development store information about their R\&D projects, their spending on innovation and the incentives used. For this purpose, analysis models were designed for the regression analysis.

Therefore, the purpose of this research is to explain, through quantitative analysis, the relations between R\&D investments and the outcomes of innovation in companies benefiting from the tax waiver of the Good Law. Therefore, we prioritize the literature review on the innovation themes, investment in $\mathrm{R} \& \mathrm{D}$ as innovation capacity, innovation results and science and technology policies.

\section{INNOVATION}

Schumpeter (1934) related economic development and innovation, and incorporated aspects of economic and social structure, as well as the role of the R\&D sector in the innovative process. For the author, economic development is directly related to the process of "creative destruction", that is, the replacement of old products and consumption habits with new ones. Thus, he distinguished between 5 distinct categories of innovation: product innovation; procedural innovation; organizational innovation; market innovation; and innovation of new materials.

In Schumpeter (1942), the author disseminates the concept of creative destruction, positioning it as a propeller of innovation. In addition, it leaves the entrepreneur aside as a single factor of introduction of change and highlights the R\&D departments of companies as key elements of the innovative process.

S. Wennekers, A. V. Wennekers, Thurik, and Reynolds (2005) indicate that several studies, over the last decades, have shown that the innovation advantage has moved from large corporations to small businesses. Hence, the current need of the State to foster the generation of knowledge in large companies.

Gallouj and Weinstein (1997) affirm that the theory of innovation has been developed essentially based on the analysis of technological innovation in manufacturing activities. In most research on innovation, R\&D plays an essential role in explaining innovative business results of companies (Martínez-Román, Gamero, \& Tamayo, 2011). According to Dosi (1988), the innovations consist of a process of search, discovery, experimentation, development, imitation and adoption of new products, new processes and new organizational techniques.

In Damanpour (1991), the classifications for innovation are: administrative innovation and technical or technological innovation; product innovation and innovation in the process; radical innovation; and incremental innovation. Technical or technological innovations relate to products, services and technology of the production process. Tornatzky and Fleischer (1990) argue that technological innovation is an unusual event, during which the social organization changes (little or a lot) what is done and how it is done. Certain innovations reduce risks for individual entrepreneurs, while the risk of developing failed technology is spread by all user-producers who contribute and perhaps implement their own ideas (Freeman \& Soete, 2009).

Considering that, the incentive laws should have a logic of business behavior and that the Good Law aims to stimulate activities of directed basic research, applied research, experimental development, basic industrial technology (BIT) and technical support services related to technological innovation, this research focused on issues most related to technological innovation. 
As the realization of $\mathrm{R} \& \mathrm{D}$ activities is marked by the existence of technological risks, the state shares these risks with entrepreneurs, provided that they offer as a counterpart investments in R\&D (capacity to innovate). Brazil has an important set of instruments to support innovation. Among legal means there are those that promote interaction between the actors of innovation (stakeholders), such as the Innovation Law (Law n. 10.973, 2004) ${ }^{2}$ and the Good Law, which regulates a public policy to promote technological innovation.

The text of the Good Law, Chapter III, finds resonance in the teachings by Martínez-Román et al. (2011), Booyens (2011) and Gault and Huttner (2008) to correlate innovation with business R\&D, although, as seen, there is no consensus in the literature regarding the concept of innovation.

Having exposed the concepts about innovation and technological innovation, we proceed to the theoretical delineation of the capacity to innovate, which is the counterpart required in the policy of the Good Law.

\section{INNOVATIVE CAPACITY}

The ability of firms to compete is increasingly dependent on the ability to apply new knowledge and innovation, shaped by partnerships and interactivity among many players in the innovation system, especially companies and research institutes/universities (Svarc, Perkovic, \& Lažnjak, 2011). In this context, Iacono, Almeida and Nagano (2011) affirm that in the new paradigm of the innovative process, known as the interactive model of innovation, technology is considered a complex, multidimensional phenomenon, which takes into account the participation of various types of actors, and takes the relationship between science and technological and economic development from an interactive view aimed at multidisciplinary learning and the development of new products and new technologies.

In this sense, Lall (1992) points out that innovation is a process dependent on a technological capability. The concept of technological capability refers to the ability to develop and exploit commercial knowledge (Fagerberg \& Srholec, 2008). An important example is the ability to innovate, which Kim (1997) termed as innovative capacity. One of the justifications for using technological capacity indicators is that they represent a sine qua non, absorb and diffuse technological innovations by an economic system (Archibugi, Denni, \& Filippetti, 2009).

Fagerberg and Srholec (2008) cited as indicators associated with different aspects of technological capacity: patents, Certifications, ISO 9000 and access to finance. In some cases, the capacity to innovate is related to the innovative organizational culture, internal processes and the ability to respond adequately to changes in the environment, allowing the organization to adapt to the competition and market. In terms of innovative capacity, there is a predominance of internal sources, as opposed to sources outside the company (Martínez-Román et al., 2011).

These authors present as variables of innovative capacity related: to the structure (age, size, sources of capital or financing and sector of activity); to the innovative strategy (knowledge bases, R\&D effort

\footnotetext{
${ }^{2}$ The Innovation Law is organized around 3 axes: 1) the creation of an environment conducive to strategic partnerships between universities, technological institutes and companies; 2) stimulating the participation of science and technology institutions in the innovation process; and 3) the incentive to innovation in the company, by means of the economic subsidy to companies for the technological development and by the use of the governmental purchasing power.
} 
and way of acquiring knowledge); competitive strategy (cooperation and internationalization); to the environment (level of competition, institutional support); related to the organization and management of innovation in companies.

Innovative capacity refers to the ability to bring great improvements and modifications to existing technologies and create new technologies. The analysis of innovative capacity performance is based on 5 dimensions: innovative capacity in the organization; innovative capacity in process; innovative capacity in service and innovative capacity in product; and innovative capacity in marketing (MartínezRomán et al., 2011).

Along with the development of innovative theories there has been increasing interest in innovative capacity measures. In general, there are 2 ways to develop innovative measures. Output type measures are linked to actual results of successful use of innovative capacity, such as patents and licenses. Input type measures refer to R\&D expenditures or training resources (Tura, Harmaakorpi, \& Pekkola, 2008).

In Valladares, Vasconcellos, and Serio (2014), the definition used for innovative capacity is the same as for Peng, Schroeder, and Shah (2008, p. 735), for whom "innovative capacity is strength or the proficiency of a set of organizational practices for the development of new products/processes". Technological innovations in products and processes include the implantation of technologically new products and processes and substantial technological improvements in products and processes (Organization for Economic Co-operation and Development [OECD], 2004).

Once established the premises that punctuate the role of the State in the induction of innovative activities, due to the technological risk involved, we next analyze the theoretical framework of the public policies of science, technology and innovation.

\section{SCIENCE, TECHNOLOGY AND INNOVATION POLICIES}

Currently, all major developed countries have relatively high degrees of intervention in industrial policy. "What primarily distinguishes the various countries are the instruments, the institutional arrangements and the philosophy of intervention" (Cimoli, Dosi, Nelson, \& Stiglitz, 2007). According Lundvall and Borrás (2005), the main objectives of industrial innovation policies are economic growth and international competitiveness.

Several government support programs for R\&D and innovation support mainly: high-tech enterprises to innovate; diffusion of technology; scientific research and technology development (Booyens, 2011). Thus, if the innovative capacity is the driving force behind funding constraints, public policies should consider the innovative capacity an important criterion to stimulate private investment in innovation, as claimed by Hottenrott and Peters (2009).

There are a number of financing modalities necessary for an economy to stimulate investment, research, development and innovation. The objective of the financing actions is to increase knowledge and new technological possibilities that reflect new products and new methods of production (Corder \& Salles, 2006).

According to Salerno and Kubota (2008), Law n. 11.196 (2005) - known as the Good Law for reducing taxes - encourages the increase in the R\&D staff, by providing for an additional exclusion of $20 \%$ of net income, in the determination of the CSLL's actual profit and calculation basis, the expenses related to the number of employees employed by the legal entity. 
To encourage patenting in Brazil, the law provides another 20\% additional exclusion of $20 \%$ of net profit, in the determination of CSLL's actual profit and taxable income, the sum of the expenses or payments linked to $\mathrm{R} \& \mathrm{D}$, object of patent or registered cultivar. By this law, the tax benefits for technological innovation are granted in the form of tax exemption. They are disciplined in the articles 17 to 26 of the Good Law (chapter III). They are due to companies that operate under real taxation regime.

The tax incentives of the Good Law aim to stimulate the effort of companies to develop their own R\&D activities instead of buying technology or just machinery, because the law allows only the contracting of R\&D services from universities, research institutes, independent inventor or micro and small businesses.

Thus, Brazil has tax benefits for technological research and to develop, design, generate, create a new product or manufacturing process ${ }^{3}$, as well as to aggregate, to add, to gather new functionalities or characteristics to existing product or process, as well as the BIT activity and technical support services indispensable for the implementation and maintenance of facilities or equipment intended exclusively for, the execution of research, development or technological innovation projects, as well as the training of human resources (HR) dedicated to them.

The Good Law introduces a conceptual break of wide proportions: the tax incentives for R\&D are of automatic fruition, not requiring, therefore, that a project is submitted or that prior authorization is requested so that they can be enjoyed. $\mathrm{R} \& \mathrm{D}$ contracts signed with micro and small enterprises in the country and with Brazilian science and technology institutes can be considered as internal and, with this, extend to smaller companies that do not use the real profit calculation system, stimulating the formation of business networks and cooperation with universities (Salerno \& Kubota, 2008).

In analyzing the reference that gives theoretical support to the object of the study, we follow the methodology used to reach the research objective.

\section{METHOD}

The research was performed based on secondary data, made available by MCTIC through FORMR\&D; this form is answered only by companies that are beneficiaries of the Good Law, such as accounting for the period in which the incentive is used, so that questions that seek to measure impacts cannot be answered, since there are no counterfactuals for them. In addition, there are several variables that suffer from the problem of simultaneous determination, which skews the estimates.

This research can be characterized as quantitative, since it will numerically approach the data through statistical analysis (Bauer, Gaskell, \& Allum, 2002), these being descriptive (frequencies, means and standard deviations) and inferential (multiple regressions).

The information used in this research was collected by MCTIC through FORMR\&D and follows the subject's approach, which allows them to be interpreted by means of a representation in the form of the input-output model represented by Figure 1, proposed by Brown and Svenson (1988), which, in general, expresses the company's R\&D system, understood as composed of phases, among them inputs, outputs and outcomes. It includes the activities necessary for the company to start the innovation process and the results that can be measured from these activities.

\footnotetext{
${ }^{3}$ New to the company, not necessarily new to the market.
} 
RAP | Incentives for technological innovation: a study of the public policy of tax exemption in Brazil

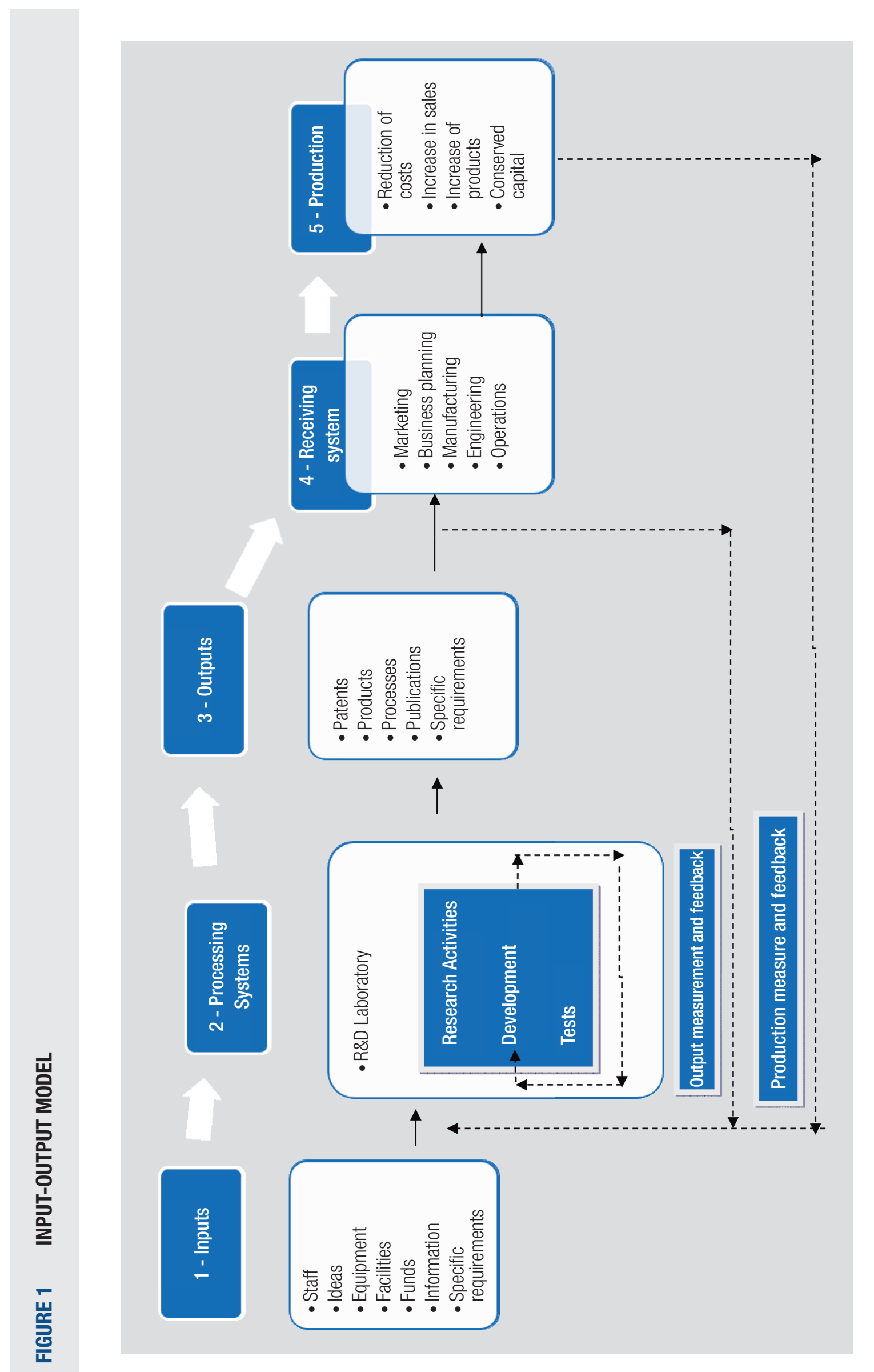

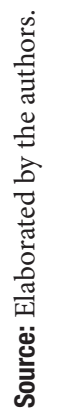

JoURnal of PUblic administration ｜ Rio de Janeiro 53(3):520-541, May - June 2019 
Synthetically, the set of information available for this study covers up to the output phase, so the empirical model used in this paper is the reduced model, transposed to a relation between the (inputs), to company - conditioned to the identification of the observed characteristics - the results of innovation (outputs and outcomes), as illustrated by Figure 2 .

\section{FIGURE 2 SIMPLIFIED INPUT-OUTPUT MODEL}

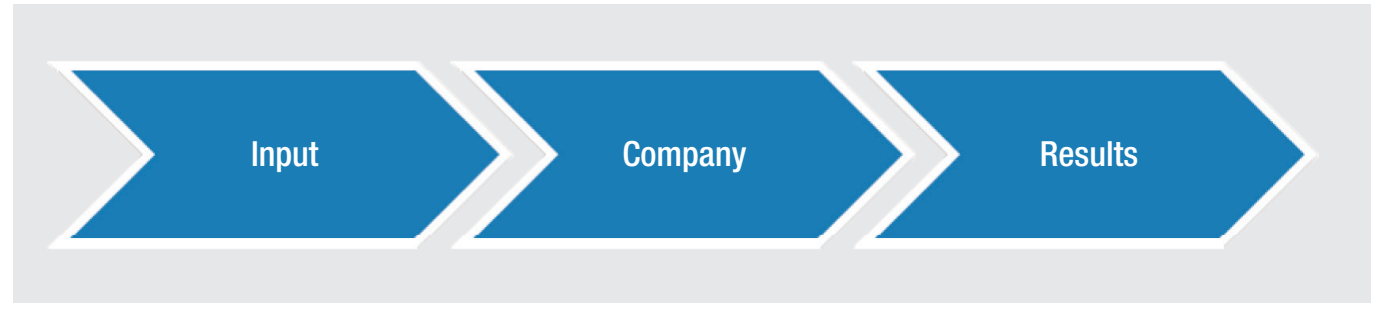

Source: Elaborated by the authors.

The study used the input-output model (Brown \& Svenson, 1988), in a simplified configuration, as an empirical strategy to answer the adopted research question. In other words, we performed several econometric and statistical analysis exercises, with the objective of identifying the relations between results of technological innovation in companies benefiting from the Good Law and the investments in $\mathrm{R} \& \mathrm{D}$ they performed.

Documentary research and analysis of the forms of companies benefiting from the Good Law were carried out during the years 2009 to 2013, which was complemented by quantitative analysis of data using Stata software.

In order to achieve the study objective, the relationships between the studied variables were verified through multiple regression analysis, since there is little systematized knowledge about the relations between the variables of the research (Tabachnick \& Fidell, 2001).

We adopted multivariate and econometric analysis techniques, such as logit models for fixed effects and linear probability models with fixed effects (Gujarati \& Porter, 2011).

For the analysis of the data, we hypothesized that the R\&D investments of the companies benefiting from the tax exemption of the Good Law generate results of technological innovation, such as product innovations, processes, services and patent.

This analysis is interested in intra-firm results and, based on data from companies that participated in the Good Law between 2009 and 2013, we verified in detail the relation between the observable characteristics of the companies of the sample, their investments in R\&D and the likelihood of companies producing innovation results, considering the possibility of positive effects, null or even negative ones related to the innovation capacities and the innovation results of firms benefited by the Good Law.

Based on the theoretical model by Brown and Svenson (1988), we studied among the companies that use the governmental support of the Good Law the variables of innovative capacity (expenditures on $R \& D$, expenditure with $H R$ on $R \& D$ ) and the outcome variables (obtaining patents, product innovation, processes and services). 
In order to verify the relationship between the observable characteristics of the companies participating in the program, some models were estimated, for binary variables, logit with fixed effects. The option by this method is mainly due to the presence of unobservable fixed effects that affect the probability of the companies innovating in a certain year.

The logit fixed effects model can be represented from the following binary dependent variable model (Honore, 1992):

$$
\begin{gathered}
y_{i t}^{*}=\beta+\varepsilon_{i t} \\
y_{i t}=1 \text { se } y_{i t}^{*} \geq 0 \text { e } 0 \quad \text { otherwise }
\end{gathered}
$$

Where $y_{i t}^{*}$ is a latent variable (not observed) that represents the amount of innovations of company $i$ in the year $t, x_{i t}$ represents the observable characteristics of firm $i$ in year $t$ that affect the quantity of innovations and $\varepsilon_{i t}$ a random error term, $y_{i t}$ is the observed variable that presents value equal to 1 when the company innovated in year $t$ and zero otherwise. In this sense, the logit model with fixed effects can be represented as follows:

$$
\operatorname{Pr}\left[y_{i t}=1 \mid x_{i t}, f_{i}\right]=\frac{\exp \left(x_{i t} \beta+f_{i}\right)}{1+\exp \left(x_{i t} \beta+f_{i}\right)}
$$

Where $f_{i}$ is the so-called fixed effect, a term that represents the intrinsic characteristics of each company, not observed, which are invariant in time and that by assumption, can be correlated with the regressors $x_{i t}$, that is:

$$
\mathrm{E}\left[f_{i} \mid x_{i t}\right] \neq 0
$$

The conditional verisimilitude approximation eliminates the individual specific effect. As an example, a company observed for 2 consecutive years can present 4 different behaviors: it may not innovate in both years $\left(y_{i 1}=y_{i 2}=0\right)$; it may innovate in both periods $\left(y_{i 1}=y_{i 2}=1\right)$; or may present changes between the years, innovating only in the first year $\left(y_{i 1}=1\right.$ e $\left.y_{i 2}=0\right)$, or only in the second year $\left(y_{i 1}=0\right.$ e $\left.y_{i 2}=1\right)$.

The logit estimator in fixed effects eliminates the presence of the fixed effect, but at the cost of eliminating from the estimation the companies that innovated in all the periods or that did not innovate in any period. In other words, by restricting the sample only to companies with variation in $y_{i t}$ in the sample years, the model can be estimated without specifying the distribution of the individual effects of the companies $f_{i}$.

The logit estimator with fixed effects $\beta^{\wedge}$ shows the effect of each dependent variable $x_{i t}$ on the logarithm of the odds ratio ${ }^{4}$. That is, the estimated coefficient of the logit model with fixed effects represents the total effect of the variable $x_{i t}$ plus the term of intrinsic effect to each company. Thus, marginal effects of response of the probability of innovation due to variations in the dependent

\footnotetext{
${ }^{4}$ The odds ratio can be represented by $P_{i t} /\left(1-P_{i t}\right)$, where $P_{i t}$ is the probability of the i-th sample company registering an innovation in year t. Thus, applying the logarithm, we have $\left(P_{i t}\right)-\log \left(1-P_{i t}\right)=x_{i t} \beta+f_{i}$.
} 
variables are not possible to be calculated, unless the value of the fixed effect term is known accurately. As the distribution of the term $f_{i}$ is unrestricted - particularly $E\left(f_{i}\right)$ is not necessarily equal to zero - it is difficult to know the exact value to replace $f_{i}$. In this sense, a common approach to calculate an approximate value for the marginal effects of logit models with fixed effects is to assume that the distribution of the fixed-effect term is normal, such that the mean is zero. From this hypothesis, the terms of fixed or intrinsic effect for each company are set at the mean, that is, they are equal to zero, by presupposition. This method, although not ideal, is capable of generating approximations of the marginal effects of the observable characteristics of the companies on the probability of innovation.

Considering the problems involved in calculating the marginal effects of the logit model with fixed effects, we also estimated a second set of linear probability models with fixed effects from the same specifications. Due to the consistency of the estimates, this second set of estimates is important, in that it can be used to support or refute the results of approximate marginal effects found in logit models with fixed effect. However, the linear probability model on an intrinsic heteroscedasticity problem due to the binary characteristic of the dependent variables, being necessary to apply correction for variance and estimating heteroscedastic matrix and with consistent autocorrelation (Wooldridge, 2010).

\subsection{Sample}

The sample is composed of 1,978 companies from various sectors of the economy who provided information to MCTIC in the years 2010 to 2014, i.e., beneficiaries of the Good Law in the base years 2009 to $2013^{5}$, being, on average, $83 \%$ of the industry, and the vast majority located in the South and Southeast regions of the country.

\section{ANALYSIS OF DATA AND RESULTS}

We defined four size ranges based on the quartiles of the distribution of the mean number of employees per company: first quartile (1 to 196 employees), second (197 to 554 employees), third (555 to 1,552 employees) and fourth quartile (1,553 or more employees), as shown in Table 1.

\section{TABLE 1 DISTRIBUTION PERCENTILE IN THE AVERAGE NUMBER OF COMPANY EMPLOYEES OVER} THE ANALYZED PERIOD

\begin{tabular}{|lc|}
\hline & Percentile (average of total employees per company from 2009 to 2013) \\
\hline $25 \%$ & 197 \\
$50 \%$ & 555 \\
$75 \%$ & 1,553 \\
Observations & 1,978 \\
Mean & $2,005.4$ \\
Standard deviation & 6,643 \\
\hline
\end{tabular}

Source: Elaborated by the authors.

\footnotetext{
${ }^{5}$ The Good Law procedure takes into account that companies use the incentives in a base year and account for the activities benefited in the following year, being prohibited the use of benefit in different period.
} 
The analysis of the information in Table 2 shows that the national capital companies are evenly distributed among the four size categories, with a slight predominance in the range of 555 and 1,553 employees. Foreign-owned companies, on the other hand, have a growing share as the number of employees increases, with the largest participation in the last quartile of size (10.4\%).

\section{TABLE 2 TOTAL RATIO OF EMPLOYEES VERSUS ORIGIN OF CAPITAL}

\begin{tabular}{|ccccc}
\hline \multirow{2}{*}{ Total employees } & \multicolumn{4}{c}{ Origin of capital } \\
& National & Mixed & Foreign & Total \\
\hline Lower than 197 & $15.0 \%$ & $1.1 \%$ & $4.0 \%$ & $20.2 \%$ \\
\hline Between 197 and 555 & $16.7 \%$ & $1.2 \%$ & $6.4 \%$ & $24.1 \%$ \\
\hline Between 555 and 1,553 & $18.1 \%$ & $1.4 \%$ & $7.6 \%$ & $27.1 \%$ \\
\hline Superior than 1,553 & $16.4 \%$ & $1.4 \%$ & $10.8 \%$ & $28.6 \%$ \\
\hline Total & $66.3 \%$ & $4.99 \%$ & $28.75 \%$ & $100.0 \%$ \\
\hline
\end{tabular}

Source: Elaborated by the authors.

Other relevant characteristics of the sampled companies that should be analyzed for a more detailed characterization of that sample are: the R\&D business structure; and receiving other government benefits. According to Table 3, of the sample companies, $84 \%$ have areas responsible for the management of technological research and development of technological innovation. In relation to the company's attitude towards the human capital of employees, only $29 \%$ of the companies have some type of HR training or development program dedicated to R\&D. Another interesting result is the fact that, among the companies benefiting from the Good Law in the period, only $6.38 \%$ received some kind of additional government support or benefit to support innovation activities.

\section{TABLE 3 OTHER RELEVANT FEATURES}

\begin{tabular}{|c|c|c|c|c|c|}
\hline \multicolumn{2}{|c|}{$\begin{array}{l}\text { There is a management area } \\
\text { in } R \& D\end{array}$} & \multicolumn{2}{|c|}{$\begin{array}{l}\text { There is HR training and } \\
\text { development programs }\end{array}$} & \multicolumn{2}{|c|}{$\begin{array}{l}\text { Other government support } \\
\text { programs were used }\end{array}$} \\
\hline Yes & No & Yes & No & Yes & No \\
\hline $84.00 \%$ & $16.00 \%$ & $29.01 \%$ & $70.99 \%$ & $6.38 \%$ & $93.62 \%$ \\
\hline
\end{tabular}

Source: Elaborated by the authors. 
We estimated the probability of a company innovating in the base year as a function of observable characteristics of the companies. The models were estimated in 3 groups $^{6}$ : for innovation in general (companies that have innovated in product, process or service); product innovation; and process innovation. Table 4 presents a characterization of the realization of innovations by the companies of the sample. To this end, innovations in products, processes or services are considered separately and together.

\section{TABLE 4 NUMBER OF SAMPLE COMPANIES BY FREQUENCY AND TYPE OF INNOVATION}

\begin{tabular}{|c|c|c|c|c|}
\hline & $\begin{array}{l}\text { Innovation in } \\
\text { some aspects }\end{array}$ & $\begin{array}{l}\text { Innovated in } \\
\text { product }\end{array}$ & $\begin{array}{l}\text { Innovated in } \\
\text { process }\end{array}$ & $\begin{array}{l}\text { Innovated in } \\
\text { service }\end{array}$ \\
\hline Not once & 656 & 773 & 1,157 & 1,647 \\
\hline At least once, but not every year & 671 & 601 & 502 & 248 \\
\hline In all the years in which he participated in the program & 652 & 605 & 320 & 84 \\
\hline
\end{tabular}

Source: Elaborated by the authors.

Table 4 shows the number of companies by type and frequency of innovations. According to statistics, approximately $1 / 3$ of the sampled companies did not innovate in any of the years in which they enjoyed the tax benefit. On the other hand, another $1 / 3$ of the companies innovated in at least one of the years in which they enjoyed the benefits of the law and the final third (652 companies) innovated in all the years in which they participated in the program. Amongst these companies that innovated in every year, the great majority presented innovations in products. A significant number of them also innovated in processes, while only 84 innovated in services. We found 39\% (773) of companies that did not innovate in product; $58 \%(1,157)$ of companies that did not innovate in process; we found $83 \%(1,647)$ who did not innovate in services, and this case is mainly explained by the prevalence of industrial companies in the sample.

Tables 5 to 7 show the marginal effects of the logit fixed effects models and the estimated coefficients of linear fixed effects models for the innovation variables in some aspect, innovation in product or process, respectively.

According to the results of Table 5, only the linear probability models showed significant impacts of observable characteristics on the probability of innovating in any aspect. However, the estimated coefficients of the 2 types of estimators are relatively close between each specification. In fact, the size of the firm is relevant in the probability of innovating. In 3 out of 5 specifications, the number

\footnotetext{
${ }^{6}$ This option was adopted because of the small number in the sample of innovative companies in services (only 84). The estimated econometric models did not confirm the hypothesis for probability of innovation in services.
} 
of employees is statistically significant. Another important factor is the origin of capital. The average company with external capital is more likely to innovate, between 0.063 and 0.086 percentage points.

Another important component is spending on $\mathrm{R} \& \mathrm{D}$, which also increases the probability of the company innovating. A $1 \%$ increase in average company spending as a proportion of revenue is associated with an increased likelihood of innovating in the range of 0.019 to 0.031 percentage points. However, it can be seen that among the components of R\&D investment, such as capital expenditures, third parties and HR dedicated to innovation, the amount spent on HR is the most relevant in determining the probability of innovation. By keeping company revenue constant, an increase in HR spending by $1 \%$ is associated with an increase in the company's chance of innovating between 0.10 and 0.11 percentage points. The results also indicate a high relation between the probability of innovation and the fact that the company received a patent, records of cultivar or other intellectual property rights. Other characteristics, such as the presence of management area in $\mathrm{R} \& \mathrm{D}$ or other forms of R\&D spending (third party expenses or capital) are not statistically significant.

\section{TABLE 5 FIXED-EFFECTS LOGIT MODELS FOR INNOVATION IN SOME ASPECT}

\begin{tabular}{|c|c|c|c|c|c|c|c|c|c|c|}
\hline \multirow{2}{*}{ Variable } & \multicolumn{2}{|c|}{ Specification (1) } & \multicolumn{2}{|c|}{ Specification (2) } & \multicolumn{2}{|c|}{ Specification (3) } & \multicolumn{2}{|c|}{ Specification (4) } & \multicolumn{2}{|c|}{ Specification (5) } \\
\hline & Logit & Linear & Logit & Linear & Logit & Linear & Logit & Linear & Logit & Linear \\
\hline \multirow{2}{*}{$\begin{array}{l}\text { Log (Total } \\
\text { Employees) }\end{array}$} & 0.012 & $0.022^{\star \star \star}$ & 0.015 & 0.011 & 0.002 & 0.006 & 0.043 & $0.036^{\star \star \star}$ & 0.043 & $0.033^{\star \star \star}$ \\
\hline & (1.341) & $(0.007)$ & $(0.252)$ & (0.008) & (0.105) & (0.008) & $(2.078)$ & $(0.009)$ & (1.814) & $(0.009)$ \\
\hline \multirow{2}{*}{$\begin{array}{l}\text { Mixed Origin of } \\
\text { Capital }\end{array}$} & -0.014 & -0.009 & -0.059 & -0.019 & -0.032 & -0.024 & -0.033 & -0.019 & -0.032 & -0.018 \\
\hline & (1.536) & $(0.048)$ & $(1.316)$ & $(0.048)$ & (1.518) & $(0.048)$ & $(1.470)$ & $(0.049)$ & (1.277) & (0.049) \\
\hline \multirow{2}{*}{$\begin{array}{l}\text { External Origin of } \\
\text { Capital }\end{array}$} & 0.036 & $0.086^{\star \star \star}$ & 0.077 & & 0.062 & & 0.066 & $0.063^{\star \star}$ & 0.075 & $0.065^{\star \star}$ \\
\hline & (3.784) & $(0.026)$ & (1.061) & $(0.026)$ & (3.232) & $(0.027)$ & $(3.274)$ & $(0.027)$ & $(3.310)$ & $(0.027)$ \\
\hline \multirow{2}{*}{ HR Program } & 0.019 & $0.034^{*}$ & 0.041 & 0.030 & & & & & & \\
\hline & (1.994) & $(0.020)$ & (0.619) & $(0.020)$ & & & & & & \\
\hline \multirow{2}{*}{$\begin{array}{l}\text { Management } \\
\text { Area in R\&D }\end{array}$} & & & 0.027 & & & & 0.014 & & 0.013 & \\
\hline & (1.510) & (0.032) & $(0.507)$ & $(0.032)$ & $(0.749)$ & (0.032) & $(0.644)$ & (0.032) & $(0.520)$ & (0.032) \\
\hline $\begin{array}{l}\text { Log (R\&D/ } \\
\text { Revenue } \\
\text { Expenditures) }\end{array}$ & & & $\begin{array}{l}0.039 \\
(0.655)\end{array}$ & $\begin{array}{l}0.019^{\star \star \star} \\
(0.005)\end{array}$ & $\begin{array}{l}0.042 \\
(2.142)\end{array}$ & $\begin{array}{l}0.031^{\star \star \star} \\
(0.008)\end{array}$ & & & & \\
\hline $\begin{array}{l}\text { Log (R\&D } \\
\text { expenditures }\end{array}$ & & & & & 0.180 & $0.110^{\star \star \star}$ & 0.187 & $0.109^{\star \star \star}$ & 0.199 & $0.104^{\star \star \star}$ \\
\hline $\begin{array}{l}\text { dedicated to } \\
\text { R\&D/Revenue) }\end{array}$ & & & & & (9.073) & $(0.040)$ & (8.932) & $(0.040)$ & $(8.420)$ & $(0.040)$ \\
\hline $\begin{array}{l}\text { Log (Third- } \\
\text { party expenses }\end{array}$ & & & & & -0.012 & 0.013 & -0.014 & 0.004 & -0.012 & 0.002 \\
\hline $\begin{array}{l}\text { dedicated to } \\
\text { R\&D/Revenue) }\end{array}$ & & & & & $(0.620)$ & $(0.084)$ & $(0.686)$ & $(0.085)$ & $(0.515)$ & $(0.084)$ \\
\hline
\end{tabular}




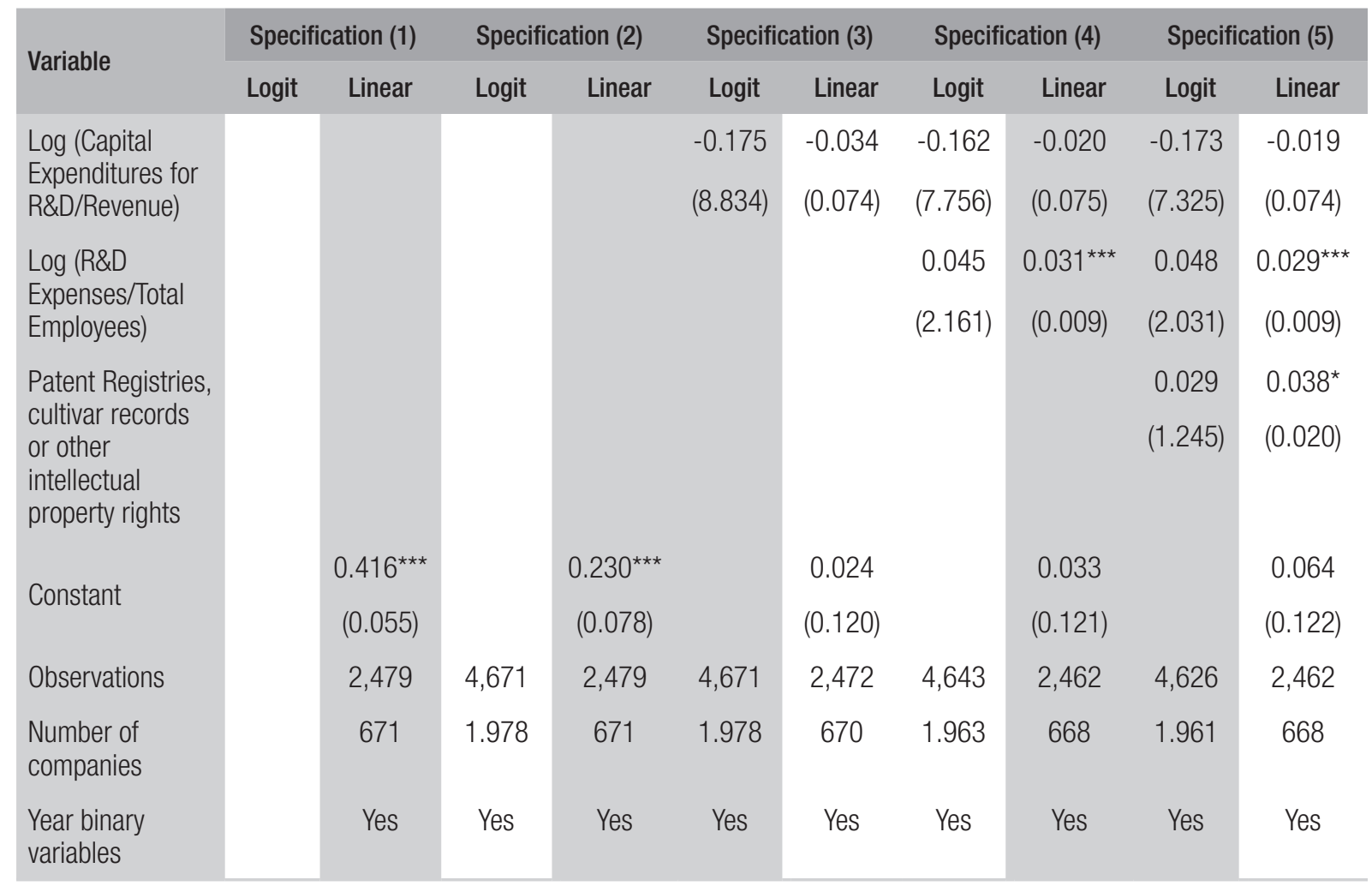

Source: Elaborated by the authors.

${ }^{* * *},{ }^{* *},{ }^{*}$ They denote statistical significance at $1 \%, 5 \%$ and $10 \%$, respectively.

Tables 6 and 7 present an analysis for each aspect in which companies can innovate separately, i.e. products or processes. According to the results of the estimates in Table 10, the important factors in determining the likelihood of a company innovating in product are the same determinants of innovation in general, but with magnitudes of intensified marginal effects. In addition, the first specification presents significant coefficients in both methods (logit and linear).

According to the results, a $1 \%$ increase in total employees increases the chances of product innovation between 0.022 and 0.048 percentage points. Companies with capital of external origin have a chance to innovate in product between 0.121 and 0.133 percentage points above the companies with capital of mixed or national origin. R\&D expenses still important for innovation. A $1 \%$ increase in $R \& D$ spending in relation to revenue is associated with increases of 0.027 to 0.05 percentage points in the chance of product innovation. In particular, if this increase occurs in HR spending, the impact increases between 0.137 and 0.142 percentage points. In addition, if $\mathrm{R} \& \mathrm{D}$ spending in relation to total staff increases by $1 \%$, the chances of product innovation are between 0.051 and 0.052 percentage points. As in the case of innovation in general, there is also a relevant relationship between the probability of product innovation and the fact that the company has received patent registrations, registration of cultivar or other intellectual property rights. 


\section{TABLE 6 FIXED-EFFECT LOGIT MODELS FOR PRODUCT INNOVATION}

\begin{tabular}{|c|c|c|c|c|c|c|c|c|c|c|}
\hline \multirow[t]{2}{*}{ Variable } & \multicolumn{2}{|c|}{ Specification (1) } & \multicolumn{2}{|c|}{ Specification (2) } & \multicolumn{2}{|c|}{ Specification (3) } & \multicolumn{2}{|c|}{ Specification (4) } & \multicolumn{2}{|c|}{ Specification (5) } \\
\hline & Logit & Linear & Logit & Linear & Logit & Linear & Logit & Linear & Logit & Linear \\
\hline \multirow[t]{2}{*}{ Log (Total Employees) } & $0.022^{\star \star}$ & 0.030 & 0.000 & 0.014 & -0.000 & 0.004 & 0.002 & $0.048^{\star \star}$ & 0.002 & $0.043^{* \star}$ \\
\hline & $(0.009)$ & $(0.019)$ & $(0.002)$ & $(0.019)$ & $(0.001)$ & $(0.020)$ & $(0.001)$ & $(0.021)$ & $(0.002)$ & $(0.021)$ \\
\hline \multirow{2}{*}{$\begin{array}{l}\text { Mixed Origin of } \\
\text { Capital }\end{array}$} & -0.073 & -0.067 & -0.011 & -0.077 & -0.003 & -0.074 & -0.003 & -0.076 & -0.004 & -0.075 \\
\hline & $(0.089)$ & $(0.100)$ & $(0.017)$ & $(0.099)$ & $(0.005)$ & $(0.099)$ & $(0.005)$ & $(0.099)$ & $(0.007)$ & $(0.099)$ \\
\hline \multirow{2}{*}{$\begin{array}{l}\text { External Origin of } \\
\text { Capital }\end{array}$} & $0.133^{* \star}$ & $0.144^{\star \star}$ & 0.013 & $0.131^{\star \star}$ & 0.003 & $0.121^{\star \star}$ & 0.004 & $0.123^{\star \star}$ & 0.006 & $0.124^{\star *}$ \\
\hline & $(0.060)$ & $(0.057)$ & $(0.014)$ & $(0.056)$ & $(0.004)$ & $(0.056)$ & $(0.005)$ & $(0.057)$ & $(0.007)$ & $(0.057)$ \\
\hline \multirow[t]{2}{*}{ HR Program } & 0.019 & 0.016 & 0.001 & 0.010 & & & & & & \\
\hline & $(0.029)$ & $(0.029)$ & $(0.004)$ & $(0.029)$ & & & & & & \\
\hline \multirow{2}{*}{$\begin{array}{l}\text { Management Area in } \\
\text { R\&D }\end{array}$} & $0.070^{*}$ & $0.071^{*}$ & 0.007 & 0.064 & 0.002 & 0.060 & 0.002 & 0.052 & 0.002 & 0.051 \\
\hline & $(0.042)$ & $(0.041)$ & $(0.008)$ & $(0.041)$ & $(0.002)$ & $(0.041)$ & $(0.002)$ & $(0.041)$ & $(0.003)$ & $(0.041)$ \\
\hline \multirow{2}{*}{$\begin{array}{l}\text { Log (R\&D/Revenue } \\
\text { Expenditures) }\end{array}$} & & & 0.005 & $0.027^{\star \star \star}$ & 0.002 & $0.050^{\star \star \star}$ & & & & \\
\hline & & & $(0.004)$ & $(0.008)$ & $(0.002)$ & $(0.014)$ & & & & \\
\hline \multirow{2}{*}{$\begin{array}{l}\text { Log (R\&D } \\
\text { expenditures } \\
\text { dedicated to R\&D/ } \\
\text { Revenue) }\end{array}$} & & & & & 0.004 & $0.142^{\star \star}$ & 0.005 & $0.142^{\star \star}$ & 0.006 & $0.137^{\star \star}$ \\
\hline & & & & & $(0.004)$ & $(0.061)$ & $(0.005)$ & $(0.061)$ & $(0.007)$ & $(0.061)$ \\
\hline \multirow{2}{*}{$\begin{array}{l}\text { Log (Third-party } \\
\text { expenses dedicated to } \\
\text { R\&D/Revenue) }\end{array}$} & & & & & -0.001 & 0.013 & -0.001 & 0.010 & -0.001 & 0.014 \\
\hline & & & & & $(0.005)$ & $(0.127)$ & $(0.005)$ & $(0.127)$ & $(0.007)$ & $(0.127)$ \\
\hline \multirow{2}{*}{$\begin{array}{l}\text { Log (Capital } \\
\text { Expenditures for R\&D/ } \\
\text { Revenue) }\end{array}$} & & & & & -0.004 & -0.051 & -0.003 & -0.015 & -0.005 & -0.014 \\
\hline & & & & & $(0.006)$ & $(0.126)$ & $(0.006)$ & $(0.130)$ & $(0.009)$ & $(0.131)$ \\
\hline \multirow{2}{*}{$\begin{array}{l}\text { Log (R\&D Expenses/ } \\
\text { Total Employees) }\end{array}$} & & & & & & & 0.002 & $0.052^{\star \star \star}$ & 0.003 & $0.051^{\star \star \star}$ \\
\hline & & & & & & & $(0.002)$ & $(0.014)$ & $(0.003)$ & $(0.014)$ \\
\hline \multirow{2}{*}{$\begin{array}{l}\text { Patent Registries, } \\
\text { cultivar records or } \\
\text { other intellectual } \\
\text { property rights }\end{array}$} & & & & & & & & & 0.002 & $0.046^{*}$ \\
\hline & & & & & & & & & $(0.003)$ & $(0.027)$ \\
\hline \multirow[t]{2}{*}{ Constant } & & $0.217^{\star}$ & & -0.058 & & $-0.421^{\star *}$ & & $-0.395^{\star}$ & & $-0.359^{*}$ \\
\hline & & $(0.123)$ & & $(0.146)$ & & $(0.209)$ & & $(0.211)$ & & $(0.211)$ \\
\hline Observations & & 1,571 & 4,036 & 1,571 & 4,036 & 1,568 & 4,010 & 1,556 & 3,996 & 1,556 \\
\hline Number of companies & & 489 & 1.867 & 489 & 1.867 & 489 & 1.851 & 485 & 1.849 & 485 \\
\hline Year binary variables & & Yes & Yes & Yes & Yes & Yes & Yes & Yes & Yes & Yes \\
\hline
\end{tabular}

Source: Elaborated by the authors.

${ }_{* * *}^{* * *},{ }^{*}$ They denote statistical significance at $1 \%, 5 \%$ and $10 \%$, respectively. 
Table 7 shows the results of the innovation process models. In this case, the factors that most impact the probability of a company innovating in process differ significantly from the other models. In fact, the only relevant factors are the total number of employees and the presence of HR training and development programs, in addition to HR spending. The results for this last variable are only statistically significant at a significance level of $10 \%$.

Increases of $1 \%$ in total average company employees increase the company's chances of innovating in process between 0.032 and 0.045 percentage points. The investment in HR is in the form of expense or in the presence of training programs are the most relevant factors to increase the chances of innovation in processes. According to the data, a $1 \%$ increase in HR spending as a proportion of revenue increases the chances of process innovation between 0.089 and 0.090 percentage points. In addition, an average company that has HR training and development programs has a probability of innovating in process superior by 0.046 percentage points to the probability of a company with the same characteristics, but does not have such programs. It is important to note that other aspects, such as the origin of capital or the total invested in R\&D in relation to revenue or total employees, which are relevant in determining innovation in general or products, are no longer relevant for innovation in processes.

\section{TABLE 7 FIXED-EFFECT LOGIT MODELS FOR PROCESS INNOVATION}

\begin{tabular}{|c|c|c|c|c|c|c|c|c|c|c|}
\hline \multirow[t]{2}{*}{ Variable } & \multicolumn{2}{|c|}{ Specification (1) } & \multicolumn{2}{|c|}{ Specification (2) } & \multicolumn{2}{|c|}{ Specification (3) } & \multicolumn{2}{|c|}{ Specification (4) } & \multicolumn{2}{|c|}{ Specification (5) } \\
\hline & Logit & Linear & Logit & Linear & Logit & Linear & Logit & Linear & Logit & Linear \\
\hline Log (Total & $0.032^{\star \star \star}$ & $0.040^{\star \star \star}$ & 0.040 & $0.041^{\star \star \star}$ & 0.012 & $0.036^{\star \star}$ & 0.014 & $0.045^{\star \star}$ & 0.015 & $0.045^{\star \star}$ \\
\hline Employees) & $(0.006)$ & $(0.015)$ & $(0.025)$ & $(0.015)$ & $(0.014)$ & $(0.015)$ & $(0.012)$ & (0.019) & $(0.012)$ & $(0.019)$ \\
\hline Mixed Origin of & 0.002 & 0.004 & 0.005 & 0.005 & 0.001 & 0.006 & -0.000 & 0.005 & -0.000 & 0.005 \\
\hline Capital & $(0.054)$ & $(0.088)$ & (0.064) & (0.088) & $(0.022)$ & $(0.087)$ & $(0.023)$ & $(0.087)$ & $(0.025)$ & $(0.087)$ \\
\hline External Origin of & -0.052 & -0.058 & -0.060 & -0.058 & -0.022 & -0.063 & -0.024 & -0.064 & -0.025 & -0.064 \\
\hline Capital & $(0.046)$ & $(0.058)$ & $(0.056)$ & $(0.058)$ & $(0.028)$ & $(0.058)$ & $(0.029)$ & $(0.059)$ & $(0.031)$ & $(0.059)$ \\
\hline HP P & 0.033 & $0.046^{\star}$ & 0.039 & $0.046^{*}$ & & & & & & \\
\hline 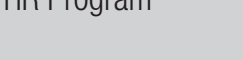 & $(0.026)$ & $(0.026)$ & $(0.035)$ & (0.026) & & & & & & \\
\hline Management Area & 0.007 & 0.005 & 0.009 & 0.005 & 0.004 & 0.008 & 0.004 & 0.008 & 0,004 & 0,008 \\
\hline in $R \& D$ & $(0.029)$ & $(0.035)$ & $(0.035)$ & (0.035) & $(0.013)$ & $(0.035)$ & $(0.014)$ & $(0.035)$ & $(0,014)$ & $(0,035)$ \\
\hline Log (R\&D/Revenue & & & -0.004 & -0.001 & 0.003 & 0.013 & & & & \\
\hline Expenditures) & & & $(0.011)$ & $(0.007)$ & $(0.003)$ & (0.013) & & & & \\
\hline $\begin{array}{l}\text { Log (R\&D } \\
\text { expenditures }\end{array}$ & & & & & 0.030 & $0.090^{*}$ & 0.032 & $0.089^{*}$ & 0.034 & 0.088 \\
\hline $\begin{array}{l}\text { dedicated to R\&D/ } \\
\text { Revenue) }\end{array}$ & & & & & $(0.029)$ & $(0.054)$ & $(0.031)$ & $(0.054)$ & $(0.032)$ & $(0.054)$ \\
\hline
\end{tabular}




\begin{tabular}{|c|c|c|c|c|c|c|c|c|c|c|}
\hline \multirow[t]{2}{*}{ Variable } & \multicolumn{2}{|c|}{ Specification (1) } & \multicolumn{2}{|c|}{ Specification (2) } & \multicolumn{2}{|c|}{ Specification (3) } & \multicolumn{2}{|c|}{ Specification (4) } & \multicolumn{2}{|c|}{ Specification (5) } \\
\hline & Logit & Linear & Logit & Linear & Logit & Linear & Logit & Linear & Logit & Linear \\
\hline $\begin{array}{l}\text { Log (Third- } \\
\text { party expenses } \\
\text { dedicated to R\&D/ } \\
\text { Revenue) }\end{array}$ & & & & & $\begin{array}{l}-0.003 \\
(0.045)\end{array}$ & $\begin{array}{l}-0.025 \\
(0.098)\end{array}$ & $\begin{array}{l}-0.004 \\
(0.048)\end{array}$ & $\begin{array}{l}-0.025 \\
(0.099)\end{array}$ & $\begin{array}{l}-0.004 \\
(0.050)\end{array}$ & $\begin{array}{l}-0.024 \\
(0.099)\end{array}$ \\
\hline $\begin{array}{l}\text { Log (Capital } \\
\text { Expenditures for } \\
\text { R\&D/Revenue) }\end{array}$ & & & & & $\begin{array}{l}0.020 \\
(0.045)\end{array}$ & $\begin{array}{l}0.031 \\
(0.122)\end{array}$ & $\begin{array}{l}0.030 \\
(0.053)\end{array}$ & $\begin{array}{l}0.063 \\
(0.124)\end{array}$ & $\begin{array}{l}0.032 \\
(0.057)\end{array}$ & $\begin{array}{l}0.063 \\
(0.124)\end{array}$ \\
\hline $\begin{array}{l}\text { Log (R\&D } \\
\text { Expenses/Total } \\
\text { Employees) }\end{array}$ & & & & & & & $\begin{array}{l}0.004 \\
(0.003)\end{array}$ & $\begin{array}{l}0.013 \\
(0.013)\end{array}$ & $\begin{array}{l}0.004 \\
(0.003)\end{array}$ & $\begin{array}{l}0.013 \\
(0.013)\end{array}$ \\
\hline $\begin{array}{l}\text { Patent Registries, } \\
\text { cultivar records or } \\
\text { other intellectual } \\
\text { property rights }\end{array}$ & & & & & & & & & $\begin{array}{c}0.003 \\
(0.010)\end{array}$ & $\begin{array}{l}0.006 \\
(0.024)\end{array}$ \\
\hline Constant & & $\begin{array}{c}0.014 \\
(0.098)\end{array}$ & & $\begin{array}{c}0.026 \\
(0.125)\end{array}$ & & $\begin{array}{l}-0.188 \\
(0.196)\end{array}$ & & $\begin{array}{l}-0.173 \\
(0.199)\end{array}$ & & $\begin{array}{l}-0,168 \\
(0.199)\end{array}$ \\
\hline Observations & & 1,247 & 4,036 & 1,247 & 4,036 & 1,245 & 4,010 & 1,238 & 3,996 & 1,238 \\
\hline $\begin{array}{l}\text { Number of } \\
\text { companies }\end{array}$ & & 390 & 1.867 & 390 & 1.867 & 390 & 1.851 & 388 & 1.849 & 388 \\
\hline $\begin{array}{l}\text { Year binary } \\
\text { variables }\end{array}$ & & Yes & Yes & Yes & Yes & Yes & Yes & Yes & Yes & Yes \\
\hline
\end{tabular}

Source: Elaborated by the authors.

***, **, ${ }^{*}$ They denote statistical significance at $1 \%, 5 \%$ and $10 \%$, respectively.

It has been realized that companies that have external capital, management area dedicated to R\&D and receive other government incentives for innovation tend to invest more in $R \& D$.

The average ratio between expenditure on $\mathrm{R} \& \mathrm{D}$ and revenue in companies that use benefits from the Good Law is around 9\%.

Among the companies in the sample, $84 \%$ are responsible for the management of technological research and development of technological innovation. In relation to the company's attitude towards the human capital of employees, only $29 \%$ of the companies have some type of HR training or development program dedicated to R\&D.

Basically, according to the statistics, on average, $65.8 \%$ of the beneficiary companies are national capital, $28.6 \%$ foreign capital and only $5.5 \%$ mixed capital.

Of the sample, 910 companies had innovation results related to patent registration at least once in the period in which they participated in the benefit, and 54\% had no records in the whole study period. For this reason, and due to the methodological limitation already explained, the models of probability of obtaining patents and other intellectual property rights were not considered. However, despite this, patents generated by subsidiaries of multinationals installed here in the country were 
identified in the sample, even the company having the policy to deposit all patents on behalf of the parent company.

Confirming the studies by Tura, Harmaakorpi, and Pekkola (2008) and by Fagerberg and Srholec (2008), which cite patents as indicators associated with different aspects of technological capacity, we verified, when analyzing the probability of obtaining patents, that both the number of employees and R\&D investments tend to increase the likelihood of receiving intellectual property rights. The presence of a more qualified staff is also relevant for obtaining patents. In addition, the probability of the company obtaining some intellectual property right also rises when the company presents some type of innovation (product, process or service).

In summary, the probability of companies that make use of the benefits of the Good Law presenting innovations in general or in products depends on the size of the company and the amount invested in $\mathrm{R} \& \mathrm{D}$, particularly investment in HR. In addition, companies with capital of external origin also have greater chances of innovating in product.

Obtaining patents, cultivar registration or other intellectual property rights is closely associated with the likelihood of product innovation.

On the other hand, the chances of companies innovating in process are limited to the size of the company, specifically targeted to HR and the presence of HR training and development programs. Therefore, HR investment seems to be crucial for innovation.

These results confirm the studies suggested by Martínez-Román et al. (2011), which present as variables of innovative capacity used in this study: company size (variable related to the company structure); and investment in R\&D (variable related to the company's innovative strategy). The results also confirmed the theory of these scholars that the company's innovative capacity performance is based on the: innovative capacity in process; innovative capacity in service; and innovative capacity product.

The results also confirm the studies by Hemert and Nijkamp (2010), for whom HR spending is an important contribution to the process of knowledge creation.

Moreover, the teachings are confirmed in Hall (2002) when it teaches that, among some peculiar characteristics that make the investment in R\&D different from the others, more than $50 \%$ of the expenses correspond to salaries of highly qualified professionals, which retain the knowledge generated by the research. Therefore, the maintenance of this knowledge depends on the ability of firms to maintain such professionals.

The econometric results suggest the contribution of the Good Law in stimulating the innovative capabilities to obtain innovation results for the set of beneficiary companies, since, excluding the tax benefits from the program, most of the companies in the sample do not receive any additional incentive for the promotion of technological innovation activities (only $6.38 \%$ of them received). Therefore, the teaching by Hottenrott and Peters (2009) that public policy must consider the ability to innovate an important criterion to stimulate private investment in innovation.

Finally, the analyzes performed with the multivariate and econometric analysis techniques of the logit fixed effects model confirm the theoretical (simplified) model of input-output, by Brown and Svenson (1988), by presenting how R\&D investments of companies benefiting from the Good Law are carried out in activities that generate results, such as product innovation, processes and services. 


\section{CONCLUSIONS}

The purpose of this research was to verify relations between R\&D investments and innovation results in companies benefiting from the tax exemption of the Good Law.

Among the theoretical constructs studied is the Science, Technology and Innovation Policy, in which the tax exemption of the Good Law is inserted as one of the main instruments of public policy, whose main purpose is to encourage innovative behavior in companies so that they become increasingly competitive.

Methodologically, this study, based on the theoretical constructs, quantitatively tested variables of capacity to innovate (investment in $\mathrm{R} \& \mathrm{D}$ ) and innovation outcomes (innovations in process, product and services, and patent) of companies benefiting from the Good Law between 2009 and 2013 to validate the theoretical proposition of the input-output model of R\&D system within companies and, thus confirming the hypothesis that the R\&D investments of the companies benefiting from the tax exemption of the Good Law generate results of technological innovation.

The econometric results affirmed the importance of the Good Law in stimulating the innovative capacities to obtain results of the innovation, such as innovations in products and processes, since they showed that, excluding the tax benefits arising from the program, most of the companies in the sample do not receive any other governmental incentives for the promotion of technological innovation activities.

In general, there are companies that use the law as a simple form of tax relief, but most seem to recognize the importance of the law to keep a qualified team on the staff establishment plan, in addition to the possibility of acquiring machinery to better equip R\&D laboratories. These companies are managing to create a culture less focused on the tax economy and more focused on innovation.

When comparing the theoretical constructs with the statistical results, we realize that the use of the Good Law has contributed to the results that companies have achieved in recent years in terms of technological innovation, mainly providing access to skilled labor.

\subsection{Limitations of the method}

The Good Law policy was implemented in 2006, but the forms that companies completed in the base years 2007 and 2008 were not electronic, which is why the definition of the sample took this into account to work the data only from the base years 2009 onwards.

One limitation found for this study was the change in the procedure for analyzing the information provided by the beneficiary companies. Therefore, the sample chosen for this study contains data of 4 years, given that from 2014, base year 2013, the MCTIC stopped collecting data on the results of the innovation in the form of analysis of the Good Law (innovation in product, process or service), which are used as variables of this research. Therefore, the temporal cut of the research refers to what is most current with regard to the data systematized by MCTIC on the Good Law.

The econometric models were estimated in 3 groups for innovation in general (companies that innovated in product, process or service); product innovation; innovation in process because, because of the small number of innovative companies in services or obtained patents or other intellectual property rights and the method used (logit with fixed effects), which requires a significant number of 
companies that started or failed to innovate during the analyzed period or obtain patents, the models of probability of innovation in services and likelihood of obtaining patents and other intellectual property rights did not present consistent results and, therefore, did not allow the study to be conclusive in this regard.

\subsection{Research agenda}

Facing the limitations pointed out in item 3.7, we suggest the following research agenda. As a continuity to the study of the behavior of companies that are beneficiaries of science and technology policies, we suggest the creation of a control group to carry out an econometric study that takes into account the sample of innovation research (PINTEC) related to the R\&D sector, respecting that the Brazilian Institute of Geography and Statistics (IBGE) organizes it this way, to verify within this sample if there are firms that could be using the Good Law and, if so, lift the reasons that led these companies not to use. With the crossing of these secondary IBGE data with the MCTIC (treatment group) it will be possible to carry out, including, a complementary field survey to obtain primary data needed to understand the behavior of these companies in relation to the Good Law, as well as to verify the impact of the tax exemption.

Thus, a group of companies that innovate, but do not use the Good Law (control group) and a group of companies that innovate and use this law (treatment group). From this it will be possible to verify whether companies receiving government support innovate less or more than unsupported firms (but which meet the legal requirements to make use of).

We also suggest studies that take into account research by sectors of the economy, since a difference in innovative behavior is expected between beneficiary companies. 


\section{REFERENCES}

Archibugi, D., Denni, M., \& Filippetti, A. (2009). The technological capabilities of nations: the state of the art of synthetic indicators. Technological Forecasting \& Social Change, 76, 917-931.

Bauer, M. W., Gaskell, G., \& Allum, N. C. (2002). Qualidade, quantidade e interesses do conhecimento. In M. W. Bauer, \& G. Gaskell (Eds.), Pesquisa qualitativa com texto, imagem e som: um manual prático (pp. 17-36). Petrópolis, RJ: Vozes.

Booyens, I. (2011). Are small, medium and microsized enterprises engines of innovation? The reality in South Africa. Science and Public Policy, 38(1), 67-78.

Brown, M. G., \& Svenson, R. A. (1988). Measuring R\&D productivity. Research Technology Management, 31(4), 11-15.

Cimoli, M., Dosi, G., Nelson, R. R., \& Stiglitz, J. (2007). Instituições e políticas moldando o desenvolvimento industrial: uma nota introdutória. Revista Brasileira de Inovação, 6(1), 55-85.

Corder, S., \& Salles, S., Filho. (2006). Aspectos conceituais do financiamento da inovação. Revista Brasileira de Inovação, 5(1), 33-76.

Dosi, G. (1988). Sources, procedures, and microeconomic effects of innovation. Journal of Economic Literature, 26(3), 1120-1171.

Fagerberg, J., \& Srholec, M. (2008). National innovation systems, capabilities and economic development. Research Policy, 37, 1417-1435.

Freeman, C., \& Soete, L. (2009). Developing science, technology and innovations indicators: what we can learn from the past. Research Policy, 38, 583-589.

Gault, F., \& Huttner, S. (2008). A cat's cradle for policy. Nature, 455, 462-463.

Gallouj, F., \& Weinstein, O. (1997). Innovation in services. Research Policy, 26, 537-556.

Gujarati, D. N., \& Porter, D. C. (2011). Econometria básica (5a ed.). Porto Alegre, RS: McGraw-Hill.

Hall, B. H. (2002). The financing of research and development. Oxford Review of Economic Policy, 18(1), 35-51.

Hemert, P. V., \& Nijkamp, P. (2010). Knowledge investments, business R\&D and innovativeness of countries: a qualitative meta-analytic comparison. Technological Forecasting \&Social Change, 77, 369-384.

Honore, B. E. (1992). Trimmed lad and least squares estimation for truncated and censored regression models with fixed effects. Econometrica, 60(3), 533-565.

Hottenrott, H., \& Peters, B. (2009, December). Innovative capability and financing constraints for innovation: more money, more innovation? (Zew Discussion Papers No. 09-081). Retrieved from http://ftp.zew.de/pub/zew-docs/dp/dp09081.pdf

Iacono, A., Almeida, C. A. S. A., \& Nagano, M. S. (2011). Interação e cooperação de empresas incubadas de base tecnológica: uma análise diante do novo paradigma da inovação. Revista de Administração Pública, 45(5), 1485-1516.

Lall, S. (1992). Technological capabilities and industrialization. World Development, 20(2), 165-186.

Lei n. 10.973, de 2 de dezembro de 2004. (2004). Dispõe sobre incentivos à inovação e à pesquisa científica e tecnológica no ambiente produtivo e dá outras providências. Brasília, DF.

Lei n. 11.196, de 21 de novembro de 2005. (2005). Institui o Regime Especial de Tributação para a Plataforma de Exportação de Serviços de Tecnologia da Informação - REPES, o Regime Especial de Aquisição de Bens de Capital para Empresas Exportadoras - RECAP e o Programa de Inclusão Digital; dispõe sobre incentivos fiscais para a inovação tecnológica; altera o Decreto-Lei n. 288, de 28 de fevereiro de 1967, o Decreto n. 70.235, de 6 de março de 1972, o Decreto-Lei n. 2.287, de 23 de julho de 1986, as Leis ns. 4.502, de 30 de novembro de 1964, 8.212 , de 24 de julho de $1991,8.245$, de 18 de outubro de 1991, 8.387, de 30 de dezembro de 1991, 8.666, de 21 de junho de 1993, 8.981, de 20 de janeiro de $1995,8.987$, de 13 de fevereiro de 1995, 8.989, de 24 de fevereiro de 1995, 9.249, de 26 de dezembro de 1995, 9.250, de 26 de dezembro de 1995, 9.311, de 24 de outubro de 1996, 9.317, de 5 de dezembro de 1996, 9.430, de 27 de dezembro de 1996, 9.718, de 27 de novembro de 1998, 10.336, de 19 de dezembro de 2001, 10.438, de 26 de abril de 2002, 10.485, de 3 de julho de 2002, 10.637, de 30 de dezembro de 2002, 10.755, de 3 de novembro de 2003, 10.833, de 29 de dezembro de 2003, 10.865, de 30 de abril de 2004, 10.925, de 23 de julho de 2004, 10.931, de 2 de agosto de 2004, 11.033, de 21 de dezembro de 2004, 11.051, de 29 de dezembro de 2004, 11.053, de 29 de dezembro de 2004, 11.101, de 9 de fevereiro de 2005, 11.128, de 28 de junho de 2005, e a Medida Provisória n. 2.199-14, de 24 de agosto de 2001; revoga a Lei n. 8.661, de 2 de junho de 1993, e dispositivos das Leis ns. 
8.668, de 25 de junho de 1993, 8.981, de 20 de janeiro de 1995, 10.637, de 30 de dezembro de 2002, 10.755, de 3 de novembro de 2003, 10.865, de 30 de abril de 2004, 10.931, de 2 de agosto de 2004, e da Medida Provisória n. 2.158-35, de 24 de agosto de 2001; e dá outras providências. Brasília, DF.

Lundvall, B.-A., \& Borrás, S. (2005). Science, technology and innovation policy. In J. Fagerberg, \& D. C. Mowery (Eds.), Innovation handbook (pp. 599-631). Oxford, England: Oxford University Press.

Martínez-Román, J. A., Gamero, J., \& Tamayo, J. A. (2011). Analysis of innovation in SMEs using an innovative capability-based non-linear model: a study in the province of Seville (Spain). Technovation, 31, 459-475.

Organização para a Cooperação e Desenvolvimento Econômico. (2004). Manual de Oslo: proposta de diretrizes para coleta e interpretação de dados sobre inovação tecnológica. Rio de Janeiro, RJ: Financiadora de Estudos e Projetos.

Peng, D. X., Schroeder, R. G., \& Shah, R. (2008). Linking routines to operations capabilities: a new perspective. Journal of Operations Management, 26(6), 730-748.

Salerno, M. S., \& Kubota, L. C. (2008). Estado e inovação. In J. A. De Negri, \& L. C. Kubota (Eds.), Políticas de incentivo à inovação tecnológica no Brasil (pp. 13-64). Brasília, DF: Instituto de Pesquisa Econômica Aplicada.
Schumpeter, J. (1934). The theory of economic development. Cambridge, MA: Harvard University Press.

Schumpeter, J. (1942). Capitalism, socialism and democracy. London, England: Harper \& Row.

Svarc, J., Perkovic, J., \& Lažnjak, J. (2011). Unintended consequences of innovation policy programmes: social evaluation of technological projects programme in Croatia. Innovation: Management, Policy \& Practice, 13, 77-94.

Tabachnick, B. G., \& Fidell, L. S. (2001). Using multivariate statistics (4a ed.). Boston, MA: Allyn and Bacon.

Tornatzky, L. G., \& Fleischer, M. (Eds.). (1990). The processes of technological innovation. Lexington, MA: Lexington Books.

Tura, T., Harmaakorpi, V., \& Pekkola, S. (2008). Breaking inside the black box: towards a dynamic evaluation framework for regional innovative capability. Science and Public Policy, 35(10), 733-744.

Valladares, P. S. D. A., Vasconcellos, M. A., \& Serio, L. C. (2014). Capacidade de inovação: revisão sistemática da literatura. Revista de Administração Contemporânea, 18(5), 598-626.

Wooldridge, J. (2010). Introdução à econometria: uma abordagem moderna (4a ed.). São Paulo, SP: Cengage Learning.

\section{Geciane Silveira Porto}

https://orcid.org/0000-0001-6104-3627

$\mathrm{PhD}$ in Administration from the University of São Paulo (USP); Professor at the Faculty of Economics, Administration and Accounting of Ribeirão Preto, University of São Paulo (FEA-RP/USP).

E-mail: geciane@usp.br

\section{Caroline Viriato Memória}

\section{https://orcid.org/0000-0001-8443-6415}

In pursue of $\mathrm{PhD}$ in Constitutional Law from the University of Fortaleza (UNIFOR); Analyst at the Ministry of Science, Technology, Innovation and Communications. E-mail: carolinememoria@hotmail.com 